Version 24 March 2016

This is a pre-edited version of an article published in: Environment and Planning D: Society and Space

Grommé, Francisca. 2016. "Provocation: technology, resistance and surveillance in public space." Environment and Planning D: Society and Space 0(0): 1-18.

doi: 10.1177/0263775816649183 [OnlineFirst]

The published article can be found on:

http://epd.sagepub.com/content/early/2016/05/20/0263775816649183.full.pdf+html [OnlineFirst]

\title{
Provocation: technology, resistance and surveillance in public space
}

\begin{abstract}
The introduction of technologies that monitor and track individuals to attribute suspicion and guilt has become commonplace in practices of order maintenance in public space. A case study of the introduction of a marker spray in Dutch urban public transport is used to conceptualise the role of technology in everyday resistances against surveillance. The introduction of this technology made available alternative subject positions. The notion of provocation is proposed for the opening up of social spaces by a technology. Through provocation, issues that do not find their expression in commonly accepted protocols and means of evidence are given a voice as a result of defiant, emotional and provisional technology usage. Attending to visible and defiant usages also opens up an agenda for examining the varying intensities at which technology operates.
\end{abstract}

Keywords: subjectivity, public space, resistance, technology, surveillance, provocation

\section{Introduction}

The introduction of technologies that monitor and track individuals to attribute suspicion and guilt has become commonplace in practices of order maintenance in public space. Examples are camera supervision and data mining, and as discussed in this article, a spray to mark suspects of threat and assault in public transport. Codemark, ${ }^{1}$ as I call this liquid marker, contained synthetic DNA and was carried by ticket inspectors.

Such technologies may affect how spaces function as 'lived spaces' (Lefebvre, 2010), i.e. they may affect the potential for a diversity of experiences, representations and selfpresentations in public space (cf. Adey, 2004; Németh and Schmidt, 2011). In this article I am interested in how spaces for reflection, struggle and resistance come into being in the context of surveillance, especially those in the context of a technology introduction. I understand lived

\footnotetext{
${ }^{1}$ I use fictitious names to guarantee the anonymity of my informants.
} 
spaces in the spirit of bell hooks' 'spaces of marginality': spaces that constitute and are constituted by the expression of alternative subjectivities (hooks, 1999; cf. Soja, 1996). These are flexible, transitory spaces that are constituted with and through everyday objects and imaginaries. The subjectivities expressed are alternative in that they are not enduringly endorsed by the relevant authorities.

My aim is not to idealise such spaces or to prescribe how they should be constituted. Instead, I aim to understand their relations with technology, and to describe their nature, problems and particularities. Even if resistances are not lasting, it is important to capture spaces for marginality, their tensions, and how they may disappear. This is especially relevant because policy makers in various domains introduce new technologies with regularity, be it for long term or short term application. Think of the introduction of corporate technologies during mega-events such as the Olympics (Bennett and Haggerty, 2011; Boyle and Haggerty, 2009), or in pilot studies (Grommé, 2015).

Authors in surveillance studies have addressed everyday resistances and struggles (Ball, 2005; Lyon, 2007). Kelly Gates, for instance, describes in detail how a facial recognition technology sparked a debate about police authority in the Tampa community (2010). We know less, however, about the agency of technology in sparking such struggles. Drawing on an ethnographic study of a pilot study on Codemark, I therefore ask how passenger and inspector subject positions were affected by Codemark's usage.

Using insights from science and technology studies (STS), specifically actor-network theory (ANT), I develop the notion of 'provocation' (Lezaun et al., 2013) to capture how technologies open up social spaces by making available alternative subject positions. Through provocation issues that do not find their expression in commonly accepted protocols and means of evidence are given a voice as a result of defiant, emotional and provisional usages of technology. Provocation thus contributes a conceptualisation of the role of technology in ad hoc struggles and resistance to the field of surveillance studies and related social science fields. It especially expresses the intensity and visibility of the work of technology. These insights, I suggest, open up an agenda for examining the varying intensities at which technology might operate in surveillance.

In what follows I first elaborate on the debate about unorganised resistance in surveillance studies and propose to study resistances through subject positioning. Next, I explain the positioning of the case as a 'surveillance situation' entailing the mutual observation between ticket inspectors and passengers. In the analysis I discuss how Codemark variously affected the expression of alternative subjectivities of passengers and inspectors during trainings, tram inspection rounds and reporting. Based on these findings I am able to attend to the role of technology in opening up these tense, and sometime self-defeating, spaces of contention. 


\section{Technology, subjectivity and spaces of resistance}

\section{Everyday resistances to surveillance}

As is widely recognised in surveillance studies and related social science fields, surveillance by states, organisations and individuals has routinely been met with organised and unorganised resistance (Lyon, 2007). In this article I am interested in ad hoc, everyday forms of struggle and resistance. An example is nurses' use of their knowledge of the hospital environment to thwart efforts to implement an RFID tracking system (Monahan and Fisher, 2011). G.T. Marx's overview of forms of resistance and non-compliance gives a systematic insight into such 'weapons of the weak' (Scott, 2008). He distinguishes between eleven forms of everyday resistance, among which 'avoidance moves', for instance workers choosing to be paid underthe-table, and 'refusal moves', including actions as simple as ignoring a question about political affiliation in a questionnaire (Marx, 2003). ${ }^{2}$

Such cases have been described as largely invisible actions arising from individuals' everyday concerns. Everyday resistances are therefore not understood as explicit ideological critiques (Gilliom and Monahan, 2012). At the same time, it is recognised that, as in the above example of hospital RFID, resistances are not strictly individual actions as they may be rooted in shared tacit knowledge and shared identities.

Unorganised subversions and struggles have been attributed varying political and theoretical relevance in surveillance studies. ${ }^{3}$ It has been argued that they serve as 'antidotes' to deterministic, panoptic theories (Lyon, 2007) because they point out that surveillance and surveillance technologies may be interpreted variably in existing discourses, and therefore do not uniformly lead to more intrusive monitoring (Gates, 2010). ${ }^{4}$ Furthermore, resistances point out that surveillance is a fragile construct, "involving the coordination, timing, and cooperation of a range of actors, which often operate across different sites" (Gad and Lauritsen, 2009, page 52). In addition, ad hoc struggles especially tend to blur the distinctions between the observer and the observed, as they highlight the agency of the latter in surveillance situations. ${ }^{5}$ Surveillance can consequently also be understood as play, or an interactive dance (Di Domenico and Ball, 2011). ${ }^{6}$ Finally, scholars have foregrounded resistances to argue for their appreciation as forms of politics. They are part of shaping new identities and places where

\footnotetext{
${ }^{2}$ Similar strategies have also been described in other literatures, for instance, in studies of the informal economy (Ustek, 2015) and migration (Broeders and Engbersen, 2007).

${ }^{3}$ Organised resistances include such initiatives as protests and privacy advocacy groups. We might also think of the efforts of NGOs to introduce counter-surveillance technologies to record police behaviour or war crimes, see Mann et al. (2002) and Wilson and Serisier (2010).

${ }^{4}$ Following Michel Foucault, some would argue that resistances reproduce and strengthen surveillance (1998).

${ }^{5}$ Such findings have also brought forward notions such as sousveillance, emphasising how technologies are turned against the dominant organisations using them (Timan and Oudshoorn, 2012).

${ }^{6}$ An 'interactive dance' does not necessarily imply equality between dance partners.
} 
individuals can control their own circumstances (Ball, 2005; Gilliom and Monahan, 2012). ${ }^{7}$ Such politics may also include the 'surveillants' refusing to operate surveillance systems as instructed (Grommé, 2012). In another idiom, it has been argued that everyday resistances might be understood as acts of citizenship, understood here as an appeal to rights (as opposed to formal law) (Isin, 2008; Isin and Ruppert, 2015).

In this article I seek to develop insights into how public spaces are opened up (or not) as spaces for ad hoc subversion and struggle. We know relatively little about how such 'lived spaces' (Lefebvre, 2010) accompany the introduction of surveillance measures. One way of thinking about this would be to assume that subjects resist because they feel threatened by a technology, or disagree with its manner of application. However, we know that resistances are situated in local histories and practices and may address issues beyond surveillance (Lyon, 2007). I choose to approach such situated resistances through examining subjectification, understood in this paper as the constitution of people as subjects, and their commitment to and recognition of their position (Ball and Wilson, 2000, page 543 [Knights 1992]; cf. Foucault, 2007).

Following Kirstie Ball and David C. Wilson (2000), I focus on how the introduction of a technology affects subject positioning. In their study of workplace supervision in the financial service industry Ball and Wilson point out that the introduction of a performance monitoring system did not lead to singular, uniform, disciplined subjects. Instead, employees positioned themselves and others as uncomfortable with or resistant to managerial regimes and the accompanying technologies. They did so in relation to varying discourses and practices, thereby showing that technologies are "enmeshed with discourses which produce and reproduce relations of power and resistance in the workplace" (page 562).

\section{Provocation}

I develop the notion of provocation to capture how the usage of technology can open up social spaces. To provoke, broadly defined, is "to call forth" (Merriam-Webster's Collegiate Dictionary, 2006). In my specific usage of the term as 'making available', I am indebted to Javier Lezaun, Fabian Muniesa and Signe Vikkelsø's (2013) analysis of a series of social science experiments from the 1930s to the 1970s. These experiments aimed to learn about 'social problems' by staging 'micro-realities'. The staged social problems typically reflected experienced threats to liberal democracies, such as authoritarianism (think of Kurt Lewin's work on group leadership). Lezaun et al. (2013) claim that these experiments were not

\footnotetext{
${ }^{7}$ In studies of categories and classification it has been shown how subjects and those responsible for everyday enforcement stretch the boundaries of pre-determined categories, and creatively use them for their own purposes, see Bowker and Star (1999), Yanow (2003).
} 
techniques for simplifying or mimicking the real. Instead, they realised social phenomena on a small scale.

The notion 'provocative containment', the authors suggest, captures the production of social reality in a confined testing environment. In cases of provocative containment, the experiment is a collection of techniques, such as dramaturgy and camera work. Together, these techniques open up a new social reality for consideration (cf. Muniesa, 2014, page 24). The idea of calling forth, inciting or making available a space for the demonstration of social problems and alternative subjectivities is relevant for the issue of resistances to surveillance. We might consider the notion of provocation to understand how spaces for resistance are opened up in uncontrolled spaces that do not necessarily stage interventions. Provocation might be an especially relevant term for resistances in public space as it suggests intensity and friction.

In their work Lezaun et al. draw on and contribute to a debate about experimentation in the field of science and technology studies (STS). Experiments and other scientific techniques are understood to be performative: they 'do' realities instead of discovering or presenting them (Haraway, 1988; Latour, 1986). I will build on a specific branch of STS, actor-network theory (ANT), to conceptualise how subjectivities are provoked. Studies in the spirit of ANT have demonstrated that the properties and status of an entity depend on a network of humans, artefacts, routines and bodies of knowledge pulled together at a particular time and place (Latour, 2012; Mol, 2002). To illustrate, in the social scientific experiments discussed above making subjects such as group leaders visible depended on establishing relations between observed behaviour and political forms.

For the situation of a technology introduction, we may understand individuals to position themselves as subjects in particular arrangements of materials, gestures and words (Munro, 2004). As in Ball and Wilson's work, subject positions may also draw on selfdefinitions and pre-existing categories (for instance, through gender identities), and involve emotional and physical dispositions (Rhodes, 1998). Moreover, subject positioning involves positioning others, as in the case of managers and employees.

I especially adopt the sensitivity of 'post'-ANT to entities that are not stable or durable (Law, 1999). From this body of work we learn that some subjects are not enacted by stable networks. They might not always be universally acknowledged, standardised or appear in dominant discourses. Their expression might therefore be more haphazard, yet persistent (Law and Singleton 2005; M'charek, 2010; cf. Star, 1990). Certain usages of technology make a range of subject positions available at a particular time and place (Munro, 2004). ${ }^{8}$

This focus on the positioning of the subject in a network of relations allows me to understand how different "lifeworlds" are made present (Munro, 2001, page 476). To relate this back to the issue of 'spaces of marginality' for the expression of alternative subject

\footnotetext{
${ }^{8} \mathrm{~A}$ relevant point to make is that even though subject positions are changeable, they are not fluid, or adopted randomly (Munro, 2004).
} 
positions, bell hooks' writings about 'homeplace' as a space of resistance is helpful. Hooks recounts how relations with the objects and aesthetics in a room taught her "how to belong in a place" and "how to recognize myself" (hooks, 1999, page 103). Spaces can thus be reconfigured as places for resistance through the expression of subjectivities otherwise not recognised. This paper will point out that even though potentially liberatory, such spaces can make one visible and vulnerable to supervision at the same time (Rhodes, 1998).

In the following, the Codemark case study serves to develop an understanding of how technology introductions, pilots and mega-events open up spaces for the expression of problems and related subjectivities. I demonstrate that technologies provoke through deviant, emotional and provisional usages. However, the case also shows that provocation is not a given. A technology might have certain properties, and agency accordingly, yet these reside in a certain set of relations and practices (Pols, 2011). I suggest that the materiality of a technology provoked the actors, yet it did so on the basis of a local history of technology usage and debates. Before further developing the notion of provocation through the empirical material, I first introduce and position the case study.

\section{Analytical positioning of the case: surveillance situations}

In 2010 and 2011 a public transport company I refer to as Tramcom introduced a substance called Codemark to the practices of its ticket inspectors. Supplied by a small security firm, Codemark is a transparent liquid containing synthetic DNA; an industrially manufactured string of fifteen to twenty base-pairs (DNA's molecular building blocks). The string functions as a 'code' that can be sprayed on an assailant's body. In the case that the sprayed person was caught by the police within a week's time, the code found on the body of the alleged offender could be matched with the spray can's code.

Worn in a canister on the inspectors' belts, management hoped that the new technology would 'empower' the inspectors. Dutch ticket inspectors have increasingly reported verbal and physical abuse over the past five years; a problem reported by various authorities inside and outside the Netherlands. ${ }^{9}$ The measure was to prevent assault, rather than be used in court, by making potential perpetrators aware that they could be tracked and traced; a disciplinary idea. One of the underlying ideas was that Codemark would increase surveillance by peer groups. The scenario was that perpetrators of insult and abuse were also frequent visitors of nightlife, and as Codemark lights up under UV-light, they would be revealed as offenders to their own social group during club nights.

\footnotetext{
${ }^{9}$ Tramcom recorded 67 cases of violent assault, 78 cases of threat and 158 cases of 'aggression' in the first six months of 2011 (Tramcom, 2012c).
} 
I followed the pilot for fourteen months as part of a larger research project. Observing the pilot 'in action' allowed me to learn the frictions and rearrangements that usually are not mentioned in evaluation reports and press statements. During this period I accompanied different inspection teams during their shifts (dressed in plain clothes, whereas inspectors usually wear uniforms), attended training sessions and conducted interviews with Codemark's supplier, public transportation management, inspectors and team leaders. Tramcom also kindly allowed me to study project documentation. The interviews were semi-structured (eighteen in total), while observations of inspection rounds (eight shifts of about six hours) allowed for insights into everyday practice and conversations about their methods and past events. In addition, I travelled in trams as a passenger, attended neighbourhood safety meetings, technology demonstrations and inspector trainings.

As will become clear from the account of the pilot study, Codemark did not indisputably become a technology for marking and tracking persons. This will therefore not be a case study about the straightforward mobilisation of Codemark to 'discipline' passengers. Rather, I position this case as a study of a 'surveillance situation', in which a variety of actors, artefacts and technologies take part. Resistances are part of surveillance situations encompassing the mutual observation between ticket inspectors and passengers. This is a mutual observation carried out by varying means and towards various aims, for instance to prove unequal treatment or to avoid inspection. All actors are vulnerable to the scrutiny of others and may act against such scrutiny (Di Domenico and Ball, 2011; Gad and Lauritsen, 2009).

The different uses of Codemark make this case study an excellent opportunity to address a challenge identified in the surveillance studies literature regarding the role of technology. The challenge, as identified by Irma van der Ploeg (2003), is to recognise that the politics of the author are implied in writing about technologies as stable and fixed entities or contingent on human practice. Whereas stressing human agency allows for identifying resistances, understanding technologies as stable entities may help identify aspects of technologies that would otherwise remain unknown. Being both interested in technology and resistance, I adopt notions from post-ANT to take technologies to be enacted variably alongside the changing relations between humans and non-humans, yet acknowledge the agency of technology in specific situations and according to local histories (Pols, 2011).

In the analysis below I will discuss various sites of Codemark usage: in pilot training sessions, in tram inspection rounds and in evaluation practices. I take these locations to be of equal importance to my analysis. These are all spaces where subject positioning occurred, in this sense training situations and reports are no less 'real' than tram inspections.

\section{Training}

Private security officers 
The pilot study started out with a half-day instruction. The tram inspectors are used to such sessions. They are trained as hosts, customer friendliness being important to Tramcom's corporate image. Over the past twenty years more responsibility for passenger safety has been transferred to public transport companies, and policing curricula have been introduced into the inspectors' professional education. The inspectors are now trained as private security officers. Dutch private security officers have limited police competences in surveillance and investigation. ${ }^{10}$ The competences they possess include writing police reports, investigation (mainly identification; only in the act) and access to city and police registers. Besides fining in the absence of a ticket, the inspectors can also issue a fine when a person cannot show a correct means of identification. ${ }^{11}$

Even though Codemark does not formally require licensing or training, Tramcom hired a private policing firm to instruct the inspectors. In an old factory now serving as a dojo, approximately fifty persons were instructed in mixed male-female groups of about fifteen inspectors. The aim was to teach the inspectors how to use Codemark preventively. The inspectors were to discourage passengers from confrontational behaviour by communicating about Codemark.

\section{Inspector identities}

The inspectors' ability to communicate about Codemark was considered crucial to its success; this was practiced in role playing exercises. In the first exercise, teams of two inspectors were asked to deliver a 'pitch' about Codemark to a passenger. On inspector Lisa and Danny's turn supervisor Henk played what he referred to as an "interested passenger":

"Interested passenger (supervisor Henk): 'What's that? Is that a candy box or something?' The inspectors do not react, and the conversation continues:

Interested passenger: 'Is that a taser [stun gun] or something?'

Danny: 'That's none of your business'.

Interested passenger: 'Are you not allowed to talk about it?'

Danny: 'Just check the internet'" (field notes, November 15, 2011).

Lisa explained their response to the group: "I would never tell people what this is. Everybody is already all ears, as it is. I really don't want to do this". Furthermore, as she and several others contended, if you do not explain anything, passengers might think it is pepper spray. As soon as passengers learn what Codemark actually is ("water with a code"), they might find out that "it's harmless, and they will laugh at you".

\footnotetext{
${ }^{10}$ See Van Steden (2008) on the privatisation of Dutch policing.

${ }^{11}$ Dutch citizens aged fourteen and older are legally required to show identification when required by appointed authorities, Dutch Identification Act, art. 2, 1993 (Wet op de Identificatieplicht, 1993).
} 
Lisa and Danny were referring to the experience of working under the scrutinizing eyes of passengers. The inspectors expressed their subjectivity as being vulnerable to the gazes and reactions of their passengers to Codemark. Lisa's remark "they will laugh at you" refers to being exposed as having less competences than officers. The inspectors also worried that Codemark would spark aggression. During one of the role playing exercises, Lisa sprayed Codemark on an 'aggressive passenger' defensively instead of explaining to him that "he will be caught by the police anyway". Lengthy explanations, the inspectors worried, would only spark aggression.

During the role plays and discussions they put several aspects of their vulnerability on display. One aspect was by making passengers visible not only as individuals, but also as groups of people and anonymous bystanders. For instance, numerous times the inspectors referred to an incident at a large square (Citysquare) to illustrate another way in which Codemark would be of use. This reference is relevant because a crowd had turned against a small group of inspectors. As Danny later said: "a situation like the Citysquare seems suitable for this [Codemark]. We needed to protect a colleague from a large group of people. Then you can say: "move or I will mark you'". Whereas Danny was interested in Codemark as a "repressive means of arrest", his colleague Roger was interested in being able to mark more suspects: "you would have three suspects instead of one". Supervisor Henk attempted to steer the discussion by proposing that Codemark could convince those who would otherwise run away to stay. All agreed with Danny's statement that "bystanders are the worst".

An additional aspect of the inspectors' vulnerability was that Codemark might jeopardize their professional identity as hosts and the relations they had built with their guests. Codemark's resemblance to a weapon ("it looks like a taser") would spark passenger aggression. In addition, the inspectors expressed their concern for the potential health effects of Codemark on passengers, as well as the possibility that passengers would be sprayed by accident and become suspects. ${ }^{12}$ By pointing this out, the inspectors' put their professional identity on display, as well its fragility.

Finally, embodied performances with Codemark expressed the inspectors' vulnerability. Earlier in the training, the inspectors were taught how to handle Codemark: how to hold it, which commands to use and how to move your body. The directions were based on pepper spray instructions for the police. The inspectors learned to assume a "fighting position": your feet are shoulder width apart and your knees are slightly bent for stability. When they sprayed, they learned, they needed to aim for the hands, and use the following command: "stop or I will mark!” Inspector Dirk and supervisor Henk tried this together.

\footnotetext{
${ }^{12}$ Codemark states that its products do not affect human health, based on contract research.
} 
"It is Dirk's turn to spray, and Henk plays the role of assailant. Dirk sprays. 'On my hands, not in the crotch!' Henk exclaims. Dirk excuses himself: 'Sorry, it's the adrenaline"" (fieldnotes, November 15, 2011).

Dirk was joking. Yet, the joke was meaningful because it foregrounded the stressful situations that the inspectors encounter by connecting Codemark to adrenaline. It expresses the loss of control and Dirk's embodied experience of this; situations missing from the role playing scenarios.

\section{Deviancy}

In Rolland Munro's words, a different lifeworld was made present through the relations between Codemark, passengers and inspectors (2001). The training hall was not only a space where inspectors learned how to control situations between passenger and inspectors. In this world, bystanders were also made present and inspectors sometimes lost control. The inspectors thus positioned themselves as subjects under scrutiny.

Codemark was part of opening up this space of resistance through defiant usages. Lisa and Danny had decided not to communicate about Codemark, hoping that passengers would think it is pepper spray. Furthermore, Codemark was performed as a candy box, as water, as pepper spray and as a means of defence. Certainly, other inspectors did use Codemark to convince passengers to cooperate. The point therefore is not that the inspectors failed, or that the scenarios were wrong. Instead, I propose that deviancy, understood here as acts that present challenging alternatives, is one of the ways in which technologies may take part in provoking resistances.

With Codemark in defiant performances, alternative subjectivities were made to stand out, in this case to Tramcom management and trainers. Codemark-as-water, for instance, underlined the vulnerability of the inspectors towards passengers and the lack of competences they experienced compared to the police. Furthermore, in relation to objects such as adrenaline and pepper spray, vulnerable, burdened and embodied inspectors were made to stand out with Codemark.

\section{Ticket inspection}

The inspectors wore Codemark in canisters on their belts during tram inspections. The canisters were visible, but the inspectors reported that after the first few months of the pilot, passengers stopped inquiring about them. Tramcom also made no further effort to attract passengers' attention to Codemark, as it cancelled the media campaign due to budget restraints. This campaign was supposed to promote awareness that inspectors could trace assailants wherever they were.

Nevertheless, Codemark did attract attention at times. In this section I present two episodes during which the inspectors used Codemark. We learn how passengers positioned 
themselves as subjects with Codemark, and how this opened up spaces for discussing the themes of accountability, authority and justice. Emotion, I propose, had a role in provoking this next to deviancy.

\section{Anchor}

My first fieldwork experience with Codemark's defiant usage in a tram was during a 'special action'. Whereas the inspectors usually remained on a vehicle for several stops, they now checked each tram at a single location and disembarked before the tram moved on.

In one tram, the inspectors encountered a tall man who wore a necklace with a large anchor pendant (I will refer to him as Anchor). Anchor was fined because he did not have a valid ticket. He became angry and four inspectors were needed to convince him to leave the tram. Anchor got on the next tram, but we soon heard loud shouting. I joined the inspectors in the tram:

“'I was not allowed to check in [validate a ticket]', Anchor says, 'this is unfair'. Six inspectors now surround him. Anchor loudly claims he is being discriminated against. According to him, another woman on the tram was allowed to validate her ticket. 'Fuck off!' he yells at inspector Danny. After that, inspector Chris tells Anchor that he is under arrest and should leave the tram" (fieldnotes, May 1, 2012).

Anchor was not only watched, he also watched the inspectors work, and he thought they were not doing their work fairly. The inspectors judged that Anchor's anger could be dangerous to other citizens and arrested him. But Anchor resisted.

"Anchor resists the arrest and he seems to reach for Chris. Ben sees this and runs to Chris. 'I will spray you', he exclaims. He pulls the can of Codemark from his belt and points it at Anchor. 'You can spray me', Anchor says. 'Stop now', Ben says. 'Spray, spray', Anchor answers, but lets the inspectors lead him to the platform ... Eight inspectors surround Anchor now. 'I have freedom of speech', Anchor says ... Ben replies that this is a case of insult, not of freedom of speech.

The group now has to wait for the police to arrive [after an arrest, the arrestee has the right to be assessed by a government authority]. Anchor is still upset. 'You are surrounding me', he says, 'can't you just take me to the police in your van? This is discrimination, you vote for Wilders, don't you?' 'True', inspector Danny answers, 'but that has nothing to do with this'. When the police arrive, they discover that Anchor was carrying a large stiletto knife in his bag. Coincidentally, carrying these types of knives is a criminal offense since today" (fieldnotes, May 1, 2012). ${ }^{13}$

Ben's alternative use of Codemark is notable. He used the command 'I will spray' instead of 'I will mark'. The former is the police command for pepper spray. Ben and several others knew

\footnotetext{
${ }^{13}$ Changes in the Act Weapons and Munition (Wet Steekwapens en Munitie) were enforced from exactly that day.
} 
this command and continued to use it to pretend they were carrying pepper spray. Later, Anchor told the inspectors that he indeed thought the inspectors were carrying pepper spray.

Codemark-as-pepper-spray did not only express the inspector's authority, it also became part of Anchor's subjectivity as a victim in an emotionally charged situation. Anchor resisted the arrest on grounds of discrimination. He is dark-skinned, in contrast to the inspectors. He accused the inspectors of voting for a politician named Geert Wilders (known for his anti-immigration politics and accused of xenophobia and racism). ${ }^{14}$ One reason for suspecting discrimination, as Anchor told the inspectors, was that another woman was allowed to validate her ticket.

The inspectors replied that this woman "was Surinamese", implying that she is of the same descent as Anchor. Therefore, the inspectors claimed that they did not discriminate. ${ }^{15}$ Anchor was surprised. He claimed that if they had told him this before, he would not have gotten this upset.

A performance with Codemark, together with the commands and gestures of pepper spray and various verbal objects of repression and injustice (discrimination, Wilders, freedom of opinion and a van to take him away), made Anchor's victimhood stand out beside his guilt. In doing so, he exposed what he thought were discriminatory inspection practices.

\section{Hat}

Ben and other inspectors estimated that about seven persons were using Codemark as pepper spray. These events usually were not formally reported because a report is only required when the substance is used to mark. Another event in which Ben used Codemark was recorded inside the organization, as Ben informed me. The second example presented in this section is a description of this video. It highlights discussions regarding inspector authority and the rightfulness of inspection.

The footage shows how Ben and three other inspectors conducted a routine inspection on a tram. Ben and his colleagues approached a group of about six young men and women between the ages of sixteen and twenty. One group member, a young man with a black woollen hat (hereafter referred to as Hat), presents a non-valid ticket. Ben tells him that he needs to fine him. Hat objects. When he entered the tram, he saw a ticket salesman in the back, so he decided to wait for him to come his way. "How am I supposed to know that you are a tram conductor?" The ticket inspectors are doing an undercover inspection today, so Hat could not recognise the inspectors by their uniform.

\footnotetext{
${ }^{14}$ Geert Wilders is the leader of a Dutch liberal nationalist and populist political party (PVV). He generates media attention with public statements that reject immigration and (what the PVV perceives as) Islamic culture.

${ }^{15}$ References to skin colour, race and ethnicity intertwine here, as they often do in Dutch debates about racism and discrimination.
} 
Ben tells Hat that if he does not cooperate, he will arrest him. After a discussion of several minutes, Ben notifies Hat that he needs to hand over his identification or "he will take Hat by the arm" [private security officers need to announce use of force]. The group of friends now becomes involved. They tell Ben that he is "not a policeman". After repeatedly asking for identification, Ben tells Hat he is under arrest, and takes him by the arm to leave the tram. Once on the platform, Hat asks Ben if he will "please stop holding his arm", in the same calm tone he has voiced during the entire incident. "I will not run away", Hat tells Ben. The latter replies: "If you do, I will spray you".

Codemark allowed inspector Ben to release Hat's arm, while at the same time demonstrating his competence to use physical force. The following discussion ensued:

Hat: "You're only doing your job. I didn't know you were a tram conductor".

Ben: "We're not tram conductors, we're inspectors. We're certified private security officers".

... Hat [calm]: "But you shouldn't take hold of my arm like that. You never know what might happen".

Ben: "That doesn't matter; we're allowed to do this. We have police competences. We can use handcuffs, everything" (video transcript).

The core of the discussion seems to be Hat's confusion about Ben's identity, is Ben a tram conductor (primarily issuing tickets) or an inspector? And when are you allowed to touch? Hat positioned himself as a concerned and confused citizen. He continued to stress that the actions of the inspectors were unjust. He furthermore made it clear that Ben put himself at risk. "You never know what might happen", he told Ben, referring to potential others who, unlike him, may not remain calm.

Hat's calm contrasts Ben's tense display of authority. In this situation, showing Codemark allowed him to maintain and specify his authority as a private security officer, as opposed to a ticket salesman or a policeman. It is interesting to note that in this case, Hat did not use Codemark to position himself as a victim, as in Anchor's case. Codemark does not always do the same things. It operates differently as part of different collectives.

\section{Emotion}

By highlighting police vans, skin colour and indeterminate "others", trams and platforms became spaces of repression, as well as spaces for contesting the authority of the inspectors. What is more, the inspectors had been made part of larger social issues including ethnicity, race, immigration and equal treatment. Importantly, accusations of discrimination went both ways in ticket inspection practices: the inspectors accused the passengers and vice versa.

Codemark was part of bringing such spaces into being. Together with skin colour, police vans, politicians and pepper spray commands and gestures, Codemark made Anchor's victimhood stand out. In the second case, Codemark nuanced inspector Ben's authority as a private security officer: to legally hold a person. Yet, Codemark did not affect Hat's position 
as a concerned and confused citizen, he strengthened his appeal to justice by bringing in "others" Ben might encounter in the future.

The foregoing is telling for how technology provoked. The actors made their identities as victims and authorities stand out with emotion, understood here as the display of feelings, such as anger, indignation, concern and fear (Bissell et al., 2012). Emotions assumed their form with-and-through Codemark, as in Anchor's anger in relation to Codemark-as-pepper-spray. In the second case, Codemark provoked in relation to inspector Ben's stressful position, an emotion foregrounded by Hat's calm and indignation. The role of emotion is also suggested in the previous section, in which the performances of Lisa, Danny and Dirk included frustration and humour.

\section{Reporting}

\section{Drowned in Codemark}

Codemark was not only used in trainings and inspections; it was also present in verbal and written reports. I use these reports to highlight another aspect of how Codemark affected subject positioning: the subjectivities provoked were provisional. It briefly highlighted positions that were not stable or formalised.

I learned about the events discussed in this section from inspector Sander. Other inspectors had told me he had used the spray, so I asked him about it. Sander told me he was working in a tram with three colleagues. He addressed a young woman who had put her feet on a bench, against Tramcom's house rules. The woman and her friend denied and were offensive and rude, Sander said.

Sander told the woman he would write a fine and asked for her identification. She attempted to flee, and a struggle ensued. Sander sprayed her with Codemark ("So I would not end up empty-handed"), after which he handcuffed her. ${ }^{16}$ At this moment, the "situation escalated", according to Sander. Bystanders in the tram turned against him. Soon the police arrived, but they had "already turned against them [the inspectors]", Sander claimed. "Bystanders" had told the police that the inspectors had used pepper spray (fieldnotes, May 30, 2012).

Sander explained that he had used Codemark on the off-chance that, if the woman fled, the police could find her and use the code to connect her to the incident. After the incident in the tram, the young woman filed a complaint with the police in which she claimed that the inspectors had used excessive force, referring to the fact that the inspectors had used force to stop the young woman from leaving the tram. She furthermore stated that Codemark had been

\footnotetext{
16 The inspectors are allowed to handcuff after the moment of arrest (Netherlands Ministry of Justice, 2011).
} 
used to harm her. In her words, she had been "drowned in Codemark". A police investigation followed, leading to a six week suspension for Sander.

A relevant subject position here, next to that of the young woman as a victim, is that of the passengers. Passengers reported Codemark as pepper spray to the police. They might have already been 'concerned citizens' critically observing the inspectors, but now they were enrolled in the situation as witnesses. Importantly, they were witnesses for another authority: the police.

By contrast, the inspectors contended that the police had not taken note of the full extent of the threat they were exposed to. During the investigation the four involved inspectors were shown CCTV footage of the incident. One day in the field, Michael and Frank, both involved in the incident, discussed the investigation:

"Michael: Four men against one girl. The police of course asked why we used four men to approach one girl. But it just looks so different on the camera images.

Frank: And you do not hear the bystanders shouting at you.

Michael: They also use stills. You only see one girl and four men" (fieldnotes July 18, 2012).

Police evidence missed something important according to the inspectors: visual and audio footage showing the bystanders. The video, therefore, did not convey the threat as experienced by the inspectors. By contrast, bystanders were given a prominent role by Sander (Tramcom, $2012 b$ ). He reported them as threats, which influenced his actions. He stated in his police report that he saw "passengers looking in my direction angrily and heard their loud shouting". Sander had used Codemark on a "bystander" who spat in his face and threatened to attack him.

Sander's report of the arrest was the main platform to express threat, vulnerability and the involvement of bystanders that turn against you. This is one of the reasons why Tramcom rigorously trains its inspectors to use standardised phrases that express the experience of threat, such as: "I did not feel safe in this situation"; "I was afraid that"; "I experienced this situation as threatening" (Tramcom, 2012b).

The use of Codemark contributed to the visibility of the vulnerable inspector because it stressed the urgency of the situation. It made this subjectivity, together with the above standard sentences and bystanders, stand out.

\section{Provisionality}

This episode first points out that the tram became a space for passenger resistance, as Codemark enrolled passengers as police witnesses. Second, and what I want to call attention to here, through the police report Tramcom management and a police station also became spaces for inspector resistance vis-à-vis policing authorities and the scrutiny of Tramcom management. The contrast between inspector reports and police evidence is interesting. Whereas police evidence is lasting, the inspectors' reports did not become part of the lasting assemblage of materials that functioned as police evidence. This suggests that provisionality is a third 
characteristic of how technology introductions can provoke alternative subjectivities and places for resistance.

These subject positionings being provisional does not mean they were arbitrary. With Codemark a relevant inspector identity that was usually not acknowledged or denied was made available at a relevant moment (Munro, 2004). This is further illustrated by the performances with Codemark during training. The inspectors as vulnerable, emotional and embodied contrast with the inspectors' use-of-force trainings. Instructions focus on one-to-one interactions and present schemes for rational decision making to de-escalate incidents. Missing from these trainings, however, is acknowledgement of the loss of control that can occur in stressful situations.

\section{Technology's capacity to provoke}

Tramcom stopped using Codemark after a year because "it had no preventive effect", as was stated in the pilot's evaluation report of June 2012. Nevertheless, discriminatory, vulnerable and irrational subjectivities "otherwise not directly available" were made to surface with Codemark (Lezaun et al., 2013: page 279). These subjectivities troubled the distributed surveillance performed by passengers, inspectors, managers and police.

In the foregoing sections I developed the concept of provocation from contained social science experiments to everyday spaces of resistance. I suggest that provocation adequately expresses the intense nature of these moments of resistance, as such resistances are characterised by emotion, deviancy and provisionality. This conception contrasts an understanding of ad hoc resistances as invisible and routine in surveillance theories (cf. Gilliom and Monahan, 2012; Marx, 2003). Before returning to this point, I will first expand on the role of the above mentioned aspects of provocation and elaborate upon the nature of Codemark's agency.

I discussed the training session to point out that provocations were characterised by defiant usage of technology. Such deviancies were acts that presented challenging, alternative uses of Codemark. This is reminiscent of the Chicago School's breaching experiments. From this category of sociological experiments we learn how deviancy can expose dominant norms and possibly denaturalise these. In this case, Codemark evoked 'alternative lifeworlds' and counter-subjectivities denaturalising the practices of maintaining order in public space (cf. Marres, 2012).

The sections also show that emotion had a relevant role to play in enabling subjectivities to surface. I do not refer to the role of emotion in provocation in a narrow sense, i.e. to cause anger or irritation. I understand emotions as practices that involve body language, artefacts and other people; as "practical engagements with the world" (Scheer, 2012, page 193). Such emotions took on their form with and through Codemark. They opened up spaces of expression beyond the dominant 'potential' of spaces (Bissell et al., 2012). 
Finally, alternative subjectivities were not necessarily lasting. Identities and their political significance can change quickly, as different relations in configurations of humans and things take shape (M'charek, 2010, 2013; Munro, 2004). Stuart Hall's notion of articulation also is helpful here. Articulations, Hall reasons in relation to political subjectivity, should be understood as temporary positionings that could also be otherwise (see interview by Grossberg, 1986). We should therefore not understand them as predetermined historical necessities, but situated accomplishments.

The example of Codemark used as pepper spray further elicits technology's capacity to provoke. The canister seemed to compel the inspectors to hold and use Codemark as if it were a canister of pepper spray. It also made the instructor use police instructions for pepper spray during the Codemark training (in slips of the tongue, he also frequently referred to Codemark as pepper spray). In the case of Sander on the tram, moreover, Codemark performed as pepper spray enrolled bystanders as witnesses against the inspectors. We should understand this agency, however, not as predetermined by the shape of the canister but as achieved in changing collectives of commands and postures and rooted in local histories. Many of the inspectors were already familiar with pepper spray routines, as they had previously been instructed from teaching material that included the use of pepper spray. They had picked information up from this material, and frequently referred to it.

Yet, given the example of Hat, who did not acknowledge the presence of Codemark, my argument is not that provocation always takes place. Pertinent are, among others, the other artefacts made relevant to a situation. Whether and how technology provokes is to be understood in each individual situation (cf. Munro, 2001).

Provocation can thus be understood as a conceptualisation of how technology can bring ad hoc spaces of resistance into being. I attended to short-lived moments of unorganised resistance that might form around the introduction of a technology in everyday situations, and showed how resistances were intertwined with local histories, practices and concerns at a site. The visible presence of Codemark foregrounded discomfort, unease and tension. Everyday resistances were therefore not invisible and routine, but visible and short-lived. An additional contribution to surveillance studies therefore is that the notion of provocation suggests the relevance of distinguishing the varying intensities at which technologies might operate, and the nature of the spaces of resistances that open up. ${ }^{17}$

Provocation, specifically, speaks to the tense and perhaps self-defeating nature of the situations discussed in this article. It operated through deviancy, yet deviancy also invited a backlash, as illustrated by Sander's suspension after his conflict with a young woman. As

\footnotetext{
${ }^{17}$ Overt resistances in relation to the symbolic roles of technology have been discussed with regard to organised resistances. In addition to footnote 3, see Martin et al.'s (2009) discussion of technology. Van der Velden (2015) shows how an anonymity tool may represent a collective counter-power in the context of the NSA disclosures.
} 
Rhodes phrased it: he only won by losing (1998, page 24). This also means that provocation should not be understood as intentional action for lasting personal gain.

\section{Conclusion}

In this article I captured how the introduction of a new technology in a surveillance practice provoked spaces of resistance. I examined how Codemark, in a collective of technologies, artefacts, words and gestures, took part in the expression of subject positions. My aim was not to idealise such spaces, but to understand their relations with technology, and to describe their nature, problems and particularities.

The subject positions expressed with Codemark are to be understood as part of the mutual surveillance between ticket inspectors, passengers, and, as the case points out, Tramcom management and the police. Broadly three sets of subjectivities were provoked, each putting the competences of inspectors, a relatively new formal policing authority in Dutch public space, up for discussion.

The first set includes passengers as suspects, concerned citizens, victims, witnesses and judges. For example, Codemark was part of a collective of artefacts, words and gestures that made Anchor not only a suspect, but also a victim. In relation to Anchor's accusations, the inspectors were made into participants to a broader social problem involving ethnicity, race and immigration. The second set included the inspectors' subject positions as vulnerable, emotional and embodied. Through defiant performances with Codemark it was made clear that inspectors cannot always conform to rational scenarios of action. Furthermore, trainings and police reports pointed out that inspectors are not always in a position of authority; they are vulnerable to the looks and actions of many others. These alternative subjectivities also highlighted passenger identities, such as 'fighters' and 'threatening bystanders'. The third set includes the inspectors' professional identities as private security officers. Codemark was performed as harmless (as water or a candy box) by the inspectors to emphasise their, in their eyes, substandard gear compared to police officers. Not being an acknowledged weapon, Codemark magnified this position. In other situations, however, Codemark as pepper spray, displayed the inspector's skills and competence to use violence.

Codemark thus temporarily opened up 'lived spaces', understood here as spaces allowing for a variety of positions and experiences beyond the original scenarios imagined by the authorities introducing the technology. A training site became a place to "see and be seen" (Soja, 1996, page 104), as inspectors demonstrated the realities of their work to their managers. A tram was not only a space for inspection, but also configured as a place of victimhood, shaped by the relations accomplished between Codemark and various artefacts and gestures, such as police vans. Finally, Codemark's role in police reports of events carved out a space of resistance for the inspectors in the formal space of police investigation and policy making. Certainly, the spaces opened up were not comfortable as they were characterised by defiance 
and tension. Even though the events of this technology introduction resulted in a decision against its permanent usage, the problems that the passengers and inspectors demonstrated did not find a place for enduring discussion.

In my analysis, I took into account an analytical challenge: understanding technologies as contingent with human usage or as fixed, and attending to the politics of choosing an approach. In order to analyse resistance I did not take Codemark's disciplining effect for granted, but examined how it was performed as, among others, a 'harmless candy box' and pepper spray. Yet, I did attribute agency (or lack thereof) to the technology as part of these performances in different situations, taking into account a local history of practices.

An additional challenge for surveillance studies that surfaced in this case study is that resistances against surveillance may be part of broader issues and problems (Lyon, 2007). A dominant issue for both inspectors and passengers in this case were the authority and the increasing competences of ticket inspectors. There is a tendency among scholars to assume that it is solely their role to address such issues. This case, however, shows that concerns about the constitutional state were at the core of surveillance.

How spaces of resistance can be provoked by technology introduction is important to understand because technologies are increasingly used in experimental and temporary situations such as pilot studies and mega-events. Such events, in Andrew Barry's words, become spaces for demonstrating truths "otherwise impossible to demonstrate in public by other means" (2001, page 178). Provocation describes how spaces of resistances can form around the introduction of a technology in surveillance practices. It hints at the intensity and visibility of such resistances, as opposed to the invisible everyday resistances described in studies of surveillance (cf. Gilliom and Monahan, 2012). Consequently, provocation thus opens up an agenda in surveillance studies and related fields to examine the varying intensities at which technology might operate in resistances.

\section{References}

Adey P, 2004, "Surveillance at the airport: surveilling mobility/mobilising surveillance" Environment and Planning A 36 1365-1380

Ball K, 2005, "Organization, surveillance and the body: towards a politics of resistance" Organization 12 89-108

Ball K, Wilson D C, 2000, "Power, control and computer-based performance monitoring: repertoires, resistance and subjectivities" Organization Studies 21 539-565

Barry A, 2001 Political Machines: Governing a Technological Society (Athlone, London) Bennett C J, Haggerty K, 2011, "Introduction: security games: surveillance and control at mega-events", in Security Games: Surveillance and Control at Mega-Events Eds C J Bennett and K Haggerty (Routledge, Abingdon; New York), pp 1-19 
Bissell D, Hynes M, Sharpe S, 2012, "Unveiling seductions beyond societies of control: affect, security, and humour in spaces of aeromobility" Environment and Planning D: Society and Space 30694 - 710

Bowker G C, Star S L, 1999 Sorting Things Out: Classification and its Consequences (The MIT Press, Cambridge, Massachusetts)

Boyle P, Haggerty K D, 2009, "Spectacular security: mega-events and the security complex" International Political Sociology 3 257-274

Broeders D, Engbersen G, 2007, “The fight against illegal migration identification policies and immigrants' counterstrategies" American Behavioral Scientist 50 1592-1609

Di Domenico M, Ball K, 2011, “A hotel inspector calls: exploring surveillance at the homework interface" Organization 18 615-636

Foucault M, 1998 The History of Sexuality: The Will to Knowledge (Penguin Books, London)

Foucault M, 2009 Security, Territory, Population: Lectures at the College de France, 197778 Ed M Senellart (Palgrave Macmillan, Basingstoke)

Gad C, Lauritsen P, 2009, "Situated Surveillance: an ethnographic study of fisheries inspection in Denmark" Surveillance \& Society 7 49-57

Gates K, 2010, “The Tampa 'Smart CCTV' experiment” Culture Unbound: Journal of Current Cultural Research 2 67-89

Gilliom J, Monahan T, 2012, "Everyday resistance", in Routledge Handbook of Surveillance Studies Eds K Ball, K Haggerty, and D Lyon (Routledge, Abingdon; New York), pp 405-411

Grommé F, 2012, "Surveillance in the supermarket: technology and the pluralisation of crime control", in Crime, Security and Surveillance: Effects for the Surveillant and the Surveilled Eds G Vande Walle, E Van den Herrewegen, and N Zurawski (Eleven International Publishing, The Hague), pp 33-53

Grommé F, 2015, “Turning aggression into an object of intervention: tinkering in a crime control pilot study" Science as Culture 24 227-247

Grossberg L, 1986, "On postmodernism and articulation: an interview with Stuart Hall” Journal of Communication Inquiry 10 45-60

Haraway D J, 1988, "Situated knowledges: the science question in feminism and the privilege of partial perspective" Feminist Studies 14 575-599

hooks b, 1999 Yearning: Race, Gender, and Cultural Politics (South End Press, Boston, MA)

Isin E F, 2008, “Theorizing acts of citizenship", in Acts of Citizenship Eds E F Isin and G M Nielsen (Palgrave Macmillan, London), pp 15-43

Isin E, Ruppert E, 2015 Being Digital Citizens (Rowman \& Littlefield International, London; New York)

Latour B, 1986 Laboratory Life: The Construction of Scientific Facts (Princeton University Press, Princeton, NJ)

Latour B, 2012 We Have Never Been Modern (Harvard University Press, Cambridge, MA) 
Law J ed, 1999 Actor Network Theory and After (Wiley-Blackwell, Oxford England; Malden, MA)

Law J, Singleton V, 2005, “Object Lessons” Organization 12(3) 331-355

Lefebvre H, 2010 Writings on Cities (Wiley-Blackwell, Cambridge, Mass, USA)

Lezaun J, Muniesa F, Vikkelsø S, 2013, "Provocative containment and the drift of socialscientific realism" Journal of Cultural Economy 6 278-293

Lyon D, 2007 Surveillance Studies: An Overview (Polity, Cambridge, UK; Malden)

Mann S, Nolan J, Wellman B, 2002, "Sousveillance: Inventing and using wearable computing devices for data collection in surveillance environments." Surveillance \& Society $1331-355$

Marres N, 2012 Material Participation: Technology, the Environment and Everyday Publics (Palgrave Macmillan, Basingstoke)

Marx G T, 2003, "A tack in the shoe: neutralizing and resisting the New Surveillance" Journal of Social Issues 59 369-390

M'charek A, 2010, "Fragile differences, relational effects: stories about the materiality of race and sex" European Journal of Women's Studies 17 307-322

M'charek A, 2013, "Beyond fact or fiction: on the materiality of race in practice" Cultural Anthropology 28 420-442

Mol A, 2002 The Body Multiple: Ontology in Medical Practice (Duke University Press, Durham and London)

Monahan T, Fisher J A, 2011, "Surveillance impediments: recognizing obduracy with the deployment of hospital information systems" Surveillance \& Society 9 1-16

Muniesa F, 2014 The Provoked Economy: Economic Reality and the Performative Turn (Routledge, London and New York)

Munro R, 2001, "Calling for accounts: numbers, monsters and membership" The Sociological Review 49 473-493

Munro R, 2004, "Punctualizing identity: time and the demanding relation" Sociology 38293 311

Németh J, Schmidt S, 2011, “The privatization of public space: modeling and measuring publicness" Environment and Planning B: Planning and Design 38 5-23

Netherlands Ministry of Justice, 2011, "Circulaire Buitengewoon Opsporingsambtenaar", The Hague

Pols J, 2011, "Wonderful webcams: about active gazes and invisible technologies" Science, Technology \& Human Values 36 451-473

Rhodes L A, 1998, "Panoptical intimacies" Public Culture 10 285-311

Scheer M, 2012, "Are emotions a kind of practice (and is that what makes them have a history)? A Bourdieuian approach to understanding emotion" History and Theory $\mathbf{5 1}$ $193-220$ 
Scott J C, 2008 Weapons of the Weak: Everyday Forms of Peasant Resistance (Yale University Press)

Soja E W, 1996 Thirdspace: Journeys to Los Angeles and Other Real-and-Imagined Places (Blackwell Publishers, Cambridge, Mass)

Star S L, 1990, "Power, technology and the phenomenology of conventions: on being allergic to onions" The Sociological Review 38(S1) 26-56

Steden R van, 2008 Privatizing Policing: Describing and Explaining the Growth of Private Security (Boom Juridische Uitgevers, The Hague)

To Provoke, 2006 Merriam-Webster's Collegiate Dictionary, kindle edition (MerriamWebster, Springfield MA)

Tramcom, 2012a, Eindevaluatie Pilotproject. Advies Implementatie

Tramcom, 2012b, Proces Verbaal van Aanhouding

Tramcom, 2012c Rapportage Tram t/m Juli 2012

Ustek F, 2015, "What is work? On the invisibility of women's paid work in the informal sector" InterDisciplines. Journal of History and Sociology 6 29-58

Van der Ploeg I, 2003, "Biometrics and privacy a note on the politics of theorizing technology" Information, Communication \& Society 6 85-104

Wet op de Identificatieplicht, December 9, 1993, Hoofdstuk II. Toonplicht, Art 2

Wilson D J, Serisier T, 2010, "Video activism and the ambiguities of counter-surveillance" Surveillance \& Society 8 166-180

Yanow D, 2003 Constructing "Race” and "Ethnicity” in America: Category-Making in Public Policy and Administration (Routledge, Abingdon; New York) 